\title{
Investment opportunities, free cash flow, and stock valuation effects of secured debt offerings
}

\author{
Shao-Chi Chang • Sheng-Syan Chen • \\ Ailing Hsing • Chia Wei Huang
}

Published online: 29 December 2006

(C) Springer Science + Business Media, LLC 2006

\begin{abstract}
This paper examines the role of investment opportunities and free cash flow in explaining the source of the stock valuation effects of secured debt offerings. We find a significantly positive relation between a firm's investment opportunities and its stock price response to announcements of secured debt issues. This evidence supports the investment opportunities hypothesis that secured debt financing is more valuable for issuing firms with high growth opportunities. In contrast, we find a lack of support for the free cash flow hypothesis. These findings hold even after controlling for other potentially influential variables. Our study provides a better understanding of the relative importance of various potential determinants in explaining the variation in the valuation impact of secured debt issues.
\end{abstract}

Keywords Secured debt $\cdot$ Investment opportunities $\cdot$ Free cash flow

JEL classification $\mathrm{G} 14 \cdot \mathrm{G} 32$

\section{S.-C. Chang}

Institute of International Business, National Cheng Kung University, Tainan, Taiwan e-mail: schang@mail.ncku.edu.tw

\section{S.-S. Chen $(\bowtie) \cdot$ C. W. Huang}

Department of Finance, College of Management, National Taiwan University, Taipei, Taiwan e-mail: fnschen@management.ntu.edu.tw

C. W. Huang

e-mail: d94723002@ntu.edu.tw

\section{A. Hsing}

Department of Finance, College of Management, Yuan Ze University, Taoyuan, Taiwan e-mail: alhsing@ms29.hionet.net 


\section{Introduction}

The use of secured debt to finance a firm's new investments may mitigate Jensen and Meckling's (1976) asset substitution problem and Myers' (1977) underinvestment problem. The asset substitution problem occurs when low-risk assets are substituted by high-risk assets once a risky fixed claim is issued, hence resulting in wealth transfer from bondholders to stockholders. This problem can be prevented through the use of secured debt financing since it makes the substitution of the firm's assets more difficult (Jackson and Kronman, 1979; Smith and Warner, 1979a, b). The underinvestment problem arises when stockholders lack incentives to contribute new capital to invest in value-increasing projects where returns are captured mainly by bondholders. Financing new profitable investment projects with secured debt alleviates this problem since it limits wealth transfer from stockholders to existing bondholders and reduces the incentives for stockholders to forego these projects (Stulz and Johnson, 1985).

The asset substitution and underinvestment problems are likely to be more serious for firms with higher growth options in their investment opportunity sets since they have more flexibility in their choice of future investments (Titman and Wessels, 1988; Barclay and Smith, 1995a, b). This suggests that secured debt financing performs better in alleviating the asset substitution and underinvestment problems for firms with more growth options. Therefore, the investment opportunities hypothesis predicts that secured debt financing is more valuable for issuing firms with high growth opportunities. A recent empirical study by Barclay and Smith (1995b) examines the determinants of various components of corporate liabilities (including secured debt) as a proportion of total long-term fixed claims (defined as capitalized leases, secured debt, ordinary claims, subordinated debt, plus preferred stock). They argue that highgrowth firms should use secured debt more intensively since secured debt financing is more valuable for those firms, but they do not find evidence consistent with this prediction.

It is important to recognize that while the issue of secured debt alleviates the underivestment problem, it may create an incentive for overinvestment. Jensen's (1986) free cash flow theory argues that potential agency conflicts arise when managers have control of cash flows in excess of those necessary for profitable investment. Potential agency costs result from managers' using the excess cash flow to overinvest in the firm so that shareholder wealth is not maximized. Because of the problems associated with free cash flow, Jensen suggests that binding managers to pay out future cash flows can reduce the agency costs associated with unprofitable investment. Debt financing is an effective method since it results in contractual agreements that force managers to make cash payments in the future. Jensen, however, notes an exception, referring to the cases in which the proceeds from a debt issue are not used to repurchase stock. Debt issues are expected to increase the free cash flow available to a firm's manager since these issues provide additional cash available to managers to be used at their discretion (Howton et al., 1998). Therefore, the overinvestment problem also potentially exists for secured debt offerings as a result of the increase in the issuing firm's free cash flow from the debt issues.

The overinvestment problem, however, is perhaps more serious for secured debt offerings than for ordinary debt offerings. Secured debt is a senior claim and generally 
has a high priority in bankruptcy (Barclay and Smith, 1995b). ${ }^{1}$ This priority in turn reduces the promised interest rate on the secured debt borrowing. The lower cost of borrowing creates an incentive for the firm to undertake excessive investment, which may take the form of accepting negative net present value (NPV) projects (Berkovitch and Kim, 1990). The positive relation between seniority/security covenants and bond prices also suggests that the sale of secured debt increases a higher amount of cash under the control of managers (Roberts and Viscione, 1984; Fridson and Gao, 2002). Therefore, if Jensen's (1986) free cash flow hypothesis holds, we expect that the value of secured debt financing is inversely related to the issuing firms' levels of existing free cash flow since the potential agency costs associated with free cash flow are higher for high-cash-flow firms. This important prediction has not yet been directly tested in the literature.

Free cash flow agency costs may depend upon a firm's investment opportunities. Firms with relatively fewer growth opportunities are more likely to have free cash flow. Therefore, the potential agency costs associated with secured debt offerings are highest for low-growth/high-cash-flow firms. The converse holds for high-growth/lowcash-flow firms. Accordingly, the free cash flow hypothesis also predicts that the value of secured debt issues is lowest (highest) for low-growth/high-cash-flow (highgrowth/low-cash-flow) firms.

Our study aims to provide direct evidence for those theoretical predictions by the investment opportunities hypothesis and Jensen's free cash flow hypothesis. While previous empirical studies have examined the overall valuation effect of secured debt issues (Eckbo, 1986) and the determinants of a firm's propensity to use secured debt (Leeth and Scott, 1989; Barclay and Smith, 1995b), our study is the first to provide a better understanding of the relative importance of the potentially influential factors in explaining the variation in the stock valuation impact of secured debt issues. The stock valuation impact is measured in terms of the abnormal stock returns to the issuing firms associated with the announcements of secured debt issues. The abnormal stock returns are the net effects on the wealth of stockholders of the firms that announce secured debt issues. The investment opportunities hypothesis predicts that the stock market's response to such announcements is more favorable for issuing firms with high growth opportunities since secured debt financing performs better in alleviating the asset substitution and underinvestment problems for those firms. The free cash flow hypothesis predicts that the stock market's response to announcements of secured debt issues is less favorable for issuing firms with high levels of existing free cash flow since those firms have higher agency costs associated with free cash flow. The free cash flow hypothesis also predicts that low-growth/high-cash-flow (high-growth/lowcash-flow) firms should have the most unfavorable (favorable) announcement-period abnormal returns since they have the highest (lowest) potential agency costs associated with secured debt issues.

We examine a sample of firms that announced secured debt issues during the period 1989-1999. We show that announcements of secured debt issues are, on average, associated with significantly negative abnormal returns, consistent with the findings in Eckbo (1986). We further divide our sample by firms with good and poor investment

\footnotetext{
${ }^{1}$ Secured debt gives the debtholders title to pledged assets until the debt is paid in full. In liquidation, secured debtholders have first claim on the pledged assets.
} 
opportunities. We find that announcing firms with favorable investment opportunities have a positive response to the announcements of their secured debt offerings whereas firms with poor investment opportunities have a negative response to such announcements. In cross-sectional regression analyses of abnormal returns, we show a significantly positive relation between the market's response to announcements of secured debt offerings and the firm's investment opportunities. Our findings support the investment opportunities hypothesis that secured debt financing is more valuable for issuing firms with high growth opportunities. We are able to find results that are consistent with the theoretical prediction on the role of growth opportunities, probably because we examine the valuation impact of secured debt issues rather than secured debt as a proportion of total liabilities on a firm's balance sheet.

In contrast, we find a lack of strong support for the free cash flow hypothesis. We do not find a significantly negative relation between the market's response to announcements of secured debt issues and the firm's free cash flow. While the subsample of low- $q$ /high-cash-flow firms is found to experience a significantly negative average abnormal return, the subsample of low- $q$ /low-cash-flow firms has the lowest and a significantly negative average abnormal return. Furthermore, the subsample of high- $q$ /high-cash-flow firms has the highest and a positive average abnormal return. These results do not support the free cash flow hypothesis. Our evidence suggests that Jensen's free cash flow theory may not apply to secured debt offerings.

Our results for the investment opportunities and free cash flow still hold even after controlling for other factors suggested in the literature that could affect the valuation impact of secured debt issues. These factors include firm and issue characteristics, such as taxes, asset riskiness, firm quality, asset specificity, firm size, regulation, and the maturity, size, and risk of the secured debt issued. We find that firms with greater asset riskiness experience significantly more favorable share price responses associated with the announcements of secured debt issues. This result is consistent with the theoretical prediction that the value of secured debt increases with the firm's likelihood of non-payment (Scott, 1977; Boot et al., 1991; Rajan and Winton, 1995; Myers and Rajan, 1998). We also find that the market's response to such announcements is more favorable for issuing firms in regulated industries. For these firms, secured debt offerings are more advantageous by prohibiting regulators from transferring wealth from investors to customers (Smith, 1986). The rest of the control variables do not significantly affect the announcement effect in our sample, suggesting that they are relatively unimportant in explaining the valuation impact of secured debt issues.

The remainder of the paper is organized as follows. Section 2 describes the sample selection and description. Section 3 presents the event study results and Section 4 presents the cross-sectional regression results. The final section concludes.

\section{Sample selection and description}

An initial sample of corporate debt issues is collected from the Securities Data Corporation's (SDC) Public Offerings database. We remove all issues other than mortgage debt, collateral debt, secured debt, and asset-backed debt issues. The sample period is from 1989 to 1999. We then search for initial announcement dates in the Wall Street Journal (WSJ). 
We use the following sample selection criteria:

1. Initial announcement date needs to be clearly identifiable in the WSJ.

2. Shares of the announcing firms are traded in any of the three largest U.S. stock markets-the New York Stock Exchange (NYSE), the American Stock Exchange (AMEX), and the NASDAQ exchange.

3. The announcements are not made by financial institutions (SIC codes 60-69) (as in Barclay and Smith, 1995b).

4. The announcing firms must have daily stock price information available from the Center for Research in Securities Prices (CRSP) returns files.

5. The announcing firms must have the measures for investment opportunities and free cash flow (to be described below) available from the Compustat files.

6. There are no other announcements seven days before or seven days after the initial announcement date in order to avoid any confounding events that could distort the measurement of the valuation effects on the announcing firms. Also excluded are the announcements of debt issues used to repurchase stock.

Our final sample comprises 247 announcements of secured debt issues by 81 different firms. Table 1 reports a distribution of the sample by calendar year and industry group. There is some clustering of announcements in our sample during 1992 through 1993, when interest rates were relatively low. However, on a daily basis the announcements are non-contemporaneous. In our sample, utilities represent about $76.9 \%$ of the announcements. This is consistent with Barclay and Smith (1995b) and Guedes and Opler (1996) who find that utilities are heavy users of secured debt.

Table 2 presents several key stylized results about bond rating, yield to maturity (YTM), and term to maturity (TTM) by describing our sample of secured debt issues. Panel A, Table 2, shows a cross-tabulation of YTM by issue rating from Moody's. There are 229 announcements of issues in which data on both bond rating and YTM are available. The majority of the secured debt issues in our sample have investment grade ratings (above $\mathrm{Ba}$ ), representing about $88.7 \%$ of the total issues. This suggests that the average credit risk for our sample of secured debt issues is relatively low and that the probability of their future payment is hence relatively high (Fridson and Gao, 2002). Guedes and Opler (1996) report similar results in their sample of mortgage bond issues. About $90.9 \%$ of the issues in our sample have YTM below $10 \%$ and the average (median) YTM for the whole sample is $8.1 \%(8.0 \%)$. Lower quality issues tend to have higher YTMs. As we move the quality of secured debt issues from ratings Aaa through single-B, there is a near monotonic increase in the average YTMs. Higher yields are required for issues with higher credit risk.

Panel B, Table 2, presents the distribution of secured debt issues by Moody's bond rating and TTM. There are 239 announcements of issues in which data on both bond rating and TTM are available. The average (median) term for the whole sample is 17 (11) years to maturity, which is slightly longer than the mean (median) term of 12 (10) years for all corporate debt issues by U.S.-based corporations between late 1982 and early 1993 as reported in Guedes and Opler (1996). There is a non-monotonic relation between credit standing and debt maturity for our sample of secured debt issues. The average maturity is shorter for issues with Aaa rating and for those with speculative grade ratings (Ba and B). This pattern accords with Diamond's $(1991,1993)$ theoretical prediction and is consistent with Stohs and Mauer (1996) who empirically document 
Table 1 Sample distribution by calendar year and industry group

\begin{tabular}{|c|c|c|c|}
\hline Year & Number of announcements & \multicolumn{2}{|c|}{ Percent of sample } \\
\hline \multicolumn{4}{|c|}{ Panel A: Sample distribution by calendar year } \\
\hline 1989 & 20 & 8.1 & \\
\hline 1990 & 21 & 8.5 & \\
\hline 1991 & 27 & 10.9 & \\
\hline 1992 & 53 & 21.5 & \\
\hline 1993 & 70 & 28.3 & \\
\hline 1994 & 15 & 6.1 & \\
\hline 1995 & 11 & 4.5 & \\
\hline 1996 & 7 & 2.8 & \\
\hline 1997 & 9 & 3.6 & \\
\hline 1998 & 8 & 3.2 & \\
\hline 1999 & 6 & 2.4 & \\
\hline Total & 247 & 100.0 & \\
\hline $\begin{array}{l}\text { Three-digit } \\
\text { SIC }\end{array}$ & Industry group & $\begin{array}{l}\text { Number of } \\
\text { announcements }\end{array}$ & Percent of sample \\
\hline \multicolumn{4}{|c|}{ Panel B: Sample distribution by industry group } \\
\hline $100-149$ & Mining & 3 & 1.2 \\
\hline 200-399 & Manufacturing & 26 & 10.5 \\
\hline $400-489$ & Transportation and communications & 3 & 1.2 \\
\hline $490-493$ & Utilities & 190 & 76.9 \\
\hline $500-519$ & Wholesale & 2 & 0.8 \\
\hline $520-599$ & Retail trade & 16 & 6.5 \\
\hline $700-899$ & Services & 7 & 2.8 \\
\hline
\end{tabular}

This table presents the distributions of announcements of secured debt issues by calendar year and industry group. There are 247 announcements of secured debt issues by 81 different firms from 1989 to 1999. The sample is collected from the Securities Data Corporation's (SDC) Public Offerings database and the Wall Street Journal (WSJ). The following sample selection criteria are used: (1) Initial announcement date needs to be clearly identifiable in the WSJ; (2) Shares of the announcing firms are traded in any of the three largest U.S. stock markets - the NYSE, the AMEX, and the NASDAQ exchange; (3) The announcements are not made by financial institutions (SIC codes 60-69); (4) The announcing firms must have daily stock price information available from the CRSP returns files; (5) The announcing firms must have the measures for investment opportunities and free cash flow available from the Compustat files; and (6) There are no other announcements seven days before or seven days after the initial announcement date. Also excluded are the announcements of debt issues used to repurchase stock. The three-digit SIC code is the first three-digit industry group code as classified by Compustat

a similar pattern by investigating a firm's entire liability structure. In Diamond's model, debt maturity choice is analyzed as a trade-off between a firm's preference for short-term debt due to private information about the future credit rating, and refinancing risk. Refinancing risk from short-term debt arises from the firm's exposure to excessive liquidations. Lenders are unwilling to refinance when bad news arrive. In Diamond's analysis, firms with the highest credit ratings issue short-term debt since this refinancing risk is small. Firms with lower credit ratings prefer long-term debt to reduce this refinancing risk. Firms with very poor credit ratings, however, are unable to borrow long-term due to the extreme adverse-selection costs. Therefore, there are two types of short-term secured debt issues: those with very good credit ratings and those with very poor credit ratings. Those in between are more likely to be long-term. 


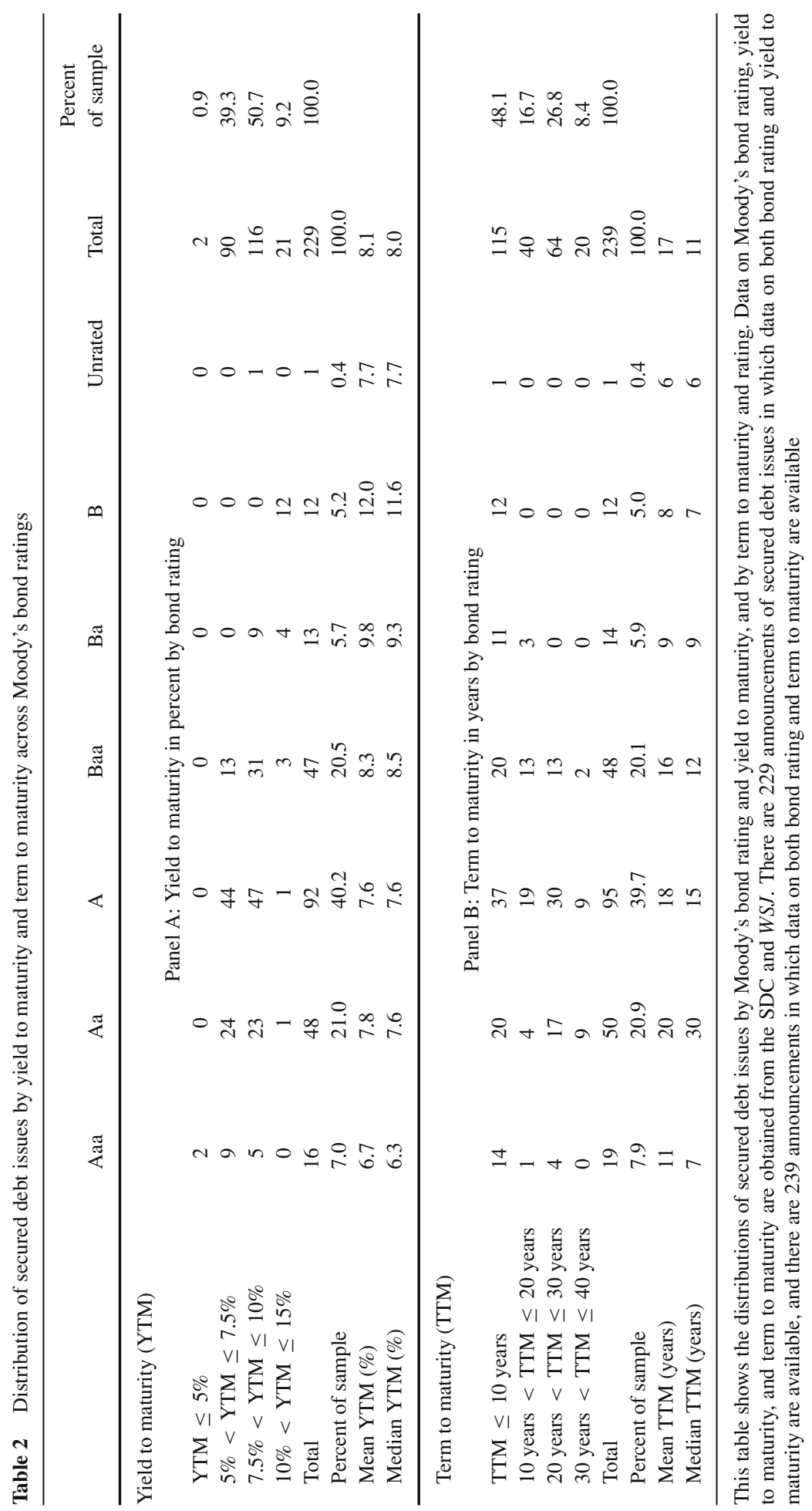


Table 3 reports the summary information of firm and issue characteristics. Data are obtained from the Compustat, SDC, and WSJ. The number of observations varies because of data availability. To empirically distinguish the effects of investment opportunities, a proxy for the profitability of new investment is needed. Tobin's $q$, defined as the ratio of the market value of a firm to the replacement costs of its assets, is perhaps the most commonly used measure of growth opportunities (Denis, 1994). The deviation of market value from replacement value depends upon the profitability of both the firm's assets in place and its expected investment opportunities. With scaleexpanding investments and decreasing marginal returns on capital, if new investment opportunities are expected to be profitable, the firm's assets in place must also be profitable and Tobin's $q$ will be high (Lang and Litzenberger, 1989). On the other hand, if the profitability of the firm's assets in place is low, its investment opportunities are also expected to earn a low rate of return and Tobin's $q$ will be low. Therefore, Tobin's $q$ is positively correlated with the profitability of new investment. Note that there is no necessary connection between the $q$ ratio and the marginal profitability of new investment opportunities. However, it seems reasonable to follow Barclay and Litzenberger (1988) and Lang and Litzenberger (1989) and assume that, on average, a measure of a firm's average profitability of investment is positively correlated with the marginal profitability of new investment.

We estimate $q$ as the ratio of the market value of the firm's assets to the book value of the firm's assets, where the market value of assets equals the market value of equity plus the liquidating value of preferred stock plus the book value of long-term debt minus the net working capital (as in Song and Walkling, 2000). ${ }^{2}$ This simple measure of $q$ for investment opportunities has been widely used in previous studies (e.g. Denis, 1994; Barclay and Smith, 1995a, b; Kang and Stulz, 1996; Stohs and Mauer, 1996; Howton et al., 1998; Holderness et al., 1999). ${ }^{3}$ Our $q$ variable is the average $q$ for the three fiscal years prior to the announcement. ${ }^{4}$ The mean (median) $q$ of our sample firms is 0.927 (0.924).

Following Lehn and Poulsen (1989), Lang et al. (1991), Howe et al. (1992), Howton et al. (1998), Lie (2000, 2002), and others, we define the free cash flow ratio as operating income before depreciation minus interest expense, taxes, preferred dividends, and common dividends for the fiscal year preceding the announcement, divided by the book value of total assets. The mean (median) free cash flow ratio of our sample firms is 0.099 (0.094).

Table 3 also provides information on the tax rate, volatility of earnings, abnormal earnings, R\&D and selling intensity, firm size, debt-equity ratio, and issue size for our sample firms. The tax rate is tax expense divided by pre-tax income for the fiscal year preceding the announcement (as in Barclay and Smith, 1995b; Sharpe

\footnotetext{
2 The conclusions in this study remain unchanged if the market value of the firm's assets is estimated as the book value of assets minus the book value of common equity plus the market value of common equity (as in Barclay and Smith, 1995a, b).

${ }^{3}$ Chung and Pruitt (1994) show that at least $96.6 \%$ of the variability of Tobin's $q$ (based on Lindenberg and Ross, 1981) is explained by this simple measure of $q$.

${ }^{4}$ This follows the approach used in Lang et al. (1991) and others. A three-year average gives a better estimate of a firm's true $q$ (Lang et al., 1989). Our results are qualitatively similar if the $q$ variable over the last year prior to the announcement is used.
} 
Table 3 Descriptive characteristics

\begin{tabular}{lllll}
\hline Variables & $N$ & Mean & Median & $\begin{array}{l}\text { Standard } \\
\text { deviation }\end{array}$ \\
\hline Tobin's $q$ & 247 & 0.927 & 0.924 & 0.268 \\
Free cash flow & 247 & 0.099 & 0.094 & 0.036 \\
Tax rate & 246 & 0.348 & 0.359 & 0.162 \\
Volatility of earnings & 247 & 0.863 & 0.137 & 4.858 \\
Abnormal earnings & 240 & -0.006 & 0.002 & 0.058 \\
R\&D and selling intensity & 247 & 0.053 & 0.000 & 0.202 \\
Firm size (\$ millions) & 247 & 10,288 & 7,357 & 13,934 \\
Debt-equity ratio & 244 & 0.970 & 0.780 & 0.714 \\
Issue size & 244 & 0.158 & 0.045 & 0.342 \\
\hline
\end{tabular}

This table presents summary information of firm and issue characteristics. Data are obtained from the Compustat files, the Securities Data Corporation's (SDC) Public Offerings database, and the WSJ. Tobin's $q$ is the average ratio of the market value of the firm's assets to the book value of the firm's assets for the three fiscal years before the announcement, where the market value of assets is estimated as the market value of equity plus the liquidating value of preferred stock plus the book value of long-term debt minus the net working capital. Free cash flow is defined as operating income before depreciation minus interest expense, taxes, preferred dividends, and common dividends, all divided by the book value of total assets, for the fiscal year preceding the announcement. The tax rate is tax expense divided by pre-tax income for the fiscal year preceding the announcement. The volatility of earnings is measured by the standard deviation of the percentage change in the announcing firm's historical earnings before depreciation, interest, and taxes for 10 years preceding the announcement. Abnormal earnings are proxied by the earnings per share in year 0 (excluding extraordinary items and discontinued operations and adjusted for any changes in shares outstanding) minus earnings per share in year -1 , divided by the share price in year -1 , where year 0 is the fiscal year in which the secured debt financing is announced. R\&D and selling intensity is measured by the sum of research and development and selling expenses divided by sales for the fiscal year preceding the announcement. Firm size is the announcing firm's market value of assets for the fiscal year prior to the announcement. Debt-equity ratio is the sum of the issuing firm's short- and long-term debt divided by the market value of common stock for the year preceding the announcement. Issue size is measured by the face value of the secured debt issue relative to the market value of common stock as of the month prior to the month of the issue. The number of observations varies because of data availability

and Nguyen, 1995 Stohs and Mauer, 1996 and others). ${ }^{5}$ The volatility of earnings is measured by the standard deviation of the percentage change in the announcing firm's historical earnings before depreciation, interest, and taxes (EBDIT) for ten years preceding the announcement (as in Titman and Wessels, 1988, MacKie-Mason, 1990). Similar to Barclay and Smith (1995b) and Stohs and Mauer (1996), abnormal earnings are proxied by the earnings per share in year 0 (excluding extraordinary items and discontinued operations and adjusted for any changes in shares outstanding) minus earnings per share in year -1 , divided by the share price in year -1 , where year 0 is the fiscal year in which the secured debt financing is announced. ${ }^{6}$ Research and development $(R \& D)$ and selling intensity is measured by the sum of R\&D and selling expenses divided by sales for the fiscal year preceding the announcement (as in Titman

\footnotetext{
$\overline{5}$ The results are similar if the tax rate variable is truncated so as to fall between zero and one, where it is set at zero for all firms with non-positive tax expense, regardless of pre-tax income, and set at one for firms that have positive taxes and negative pre-tax income (as in Sharpe and Nguyen, 1995).

${ }^{6}$ Use of the simple change in earnings is motivated by evidence in accounting and finance literature that annual earnings are well described by a random walk (Kleidon, 1986; Watts and Zimmerman, 1986).
} 
and Wessels, 1988; and others). ${ }^{7}$ Firm size is the announcing firm's market value of assets for the fiscal year prior to the announcement (as in Barclay and Smith, 1995a, $\mathrm{b}$, and others). ${ }^{8}$ The debt-equity ratio is the sum of the issuing firm's short-term and long-term debt divided by the market value of common stock for the year preceding the announcement (as in Eckbo, 1986). Finally, issue size is measured by the face value of the secured debt issue relative to the market value of common stock as of the month prior to the month of the issue (as in Eckbo, 1986).

\section{Event study results}

In this section, we first present the event study results for the whole sample. We then report the comparisons of average abnormal returns for subsamples stratified according to Tobin's $q$ and free cash flow.

\subsection{Overall sample}

We employ standard event-study methods to examine stock price responses to announcements of secured debt issues. Day 0 is defined as the initial announcement date. The abnormal return is calculated as the difference between the actual return and an expected return generated by the market model. We use the value weighted CRSP index as a proxy for market returns and estimate the parameters of the market model using the data over the period from 200 to 60 days before the initial announcement date. Abnormal returns and cumulative abnormal returns are generated for each firm announcing a secured debt issue over the period 30 days before to 30 days after the initial announcement date. Cumulative abnormal returns over the period $(-30,-2)$, $(-20,-2),(-10,-2),(-1,0),(1,10),(1,20)$, and $(1,30)$ are separately calculated by summing up the daily abnormal returns over the respective periods. The two-day period $(-1,0)$ captures the price reaction to the announcement of secured debt issues, while earlier periods capture the anticipation of the information and later periods capture early revisions to the initial reaction of the secured debt offering. Table 4 reports the results of the event study.

The average two-day $(-1,0)$ announcement-period abnormal return of our sample firms is $-0.19 \%$, significant at the $5 \%$ level. ${ }^{9}$ Furthermore, the median abnormal return is $-0.20 \%$ (also significant at the $5 \%$ level) and $55.1 \%$ of the sample announcement effects are negative, indicating that the average two-day abnormal return is not driven by outlier observations. No significant abnormal returns are observed preceding and following the announcement period. Our results are consistent with Eckbo (1986), who finds that firms offering mortgage bonds, on average, experience significantly negative two-day announcement-period abnormal returns of $-0.20 \%$.

\footnotetext{
${ }^{7}$ Qualitatively similar results are obtained if we divide by the book value of total assets for the fiscal year prior to the announcement.

${ }^{8}$ Our results are qualitatively similar if firm size is measured by the firm's book value of total assets or sales for the year prior to the announcement.

${ }^{9}$ We have also conducted significance tests in Table 4 using the Z-statistic, as described in Dodd and Warner (1983). Similar results are obtained.
} 
Table 4 Cumulative abnormal returns

\begin{tabular}{llllll}
\hline $\begin{array}{l}\text { Period relative } \\
\text { to the } \\
\text { announcement }\end{array}$ & $\begin{array}{l}\text { Mean abnormal } \\
\text { return (\%) }\end{array}$ & $t$-statistic & $\begin{array}{l}\text { Median } \\
\text { abnormal return } \\
(\%)\end{array}$ & $\begin{array}{l}\text { W-value for the } \\
\text { Wilcoxon } \\
z \text {-statistic }\end{array}$ & $\begin{array}{l}\text { Proportion } \\
\text { of negative } \\
\text { abnormal } \\
\text { returns }(\%)\end{array}$ \\
\hline$[-30,-2]$ & -0.02 & -0.03 & -0.45 & 0.36 & 54.3 \\
{$[-20,-2]$} & 0.01 & 0.03 & 0.01 & 0.98 & 49.8 \\
{$[-10,-2]$} & 0.13 & 0.51 & 0.06 & 0.76 & 49.4 \\
{$[-1,0]$} & -0.19 & $-2.02^{* *}$ & -0.20 & 0.03 & 55.1 \\
{$[1,10]$} & -0.23 & -0.83 & 0.01 & 0.51 & 49.4 \\
{$[1,20]$} & -0.40 & -1.06 & 0.07 & 0.49 & 48.6 \\
{$[1,30]$} & -0.73 & -1.50 & 0.17 & 0.47 & 48.2 \\
\hline
\end{tabular}

This table presents the cumulative abnormal stock returns surrounding the announcements of 247 secured debt issues from 1989 to 1999. Cumulative abnormal returns are estimated using the standard market model procedure with parameters estimated for the period 200 days to 60 days before the announcement. Day 0 in event time is the date of the announcement's report on the WSJ. "***" represents a 5\% significance level.

\subsection{Analysis of subsamples}

In Panel A, Table 5, we examine the importance of investment opportunities in explaining the announcement effect of secured debt offerings. The sample firms are divided according to whether the announcing firms have $q$ greater or less than one. High- $q$ firms are those with $q$ above one while low- $q$ firms are those with $q$ below one. This classification follows that of Lang et al. (1991), Howe et al. (1992), and others. High- $q$ firms are those with good investment opportunities whereas low- $q$ firms are those with poor investment opportunities.

Our results show that high- $q$ firms have a positive average two-day announcementperiod abnormal return of $0.54 \%$, statistically significant at the $5 \%$ level. The median abnormal return for high- $q$ firms is also positive, although not statistically significant. In contrast, the average and median abnormal returns for the low- $q$ firms are respectively $-0.40 \%$ and $-0.28 \%$, both statistically significant at the $1 \%$ level. The mean difference between the abnormal returns for high- $q$ and low- $q$ firms is $0.94 \%$ and is statistically significant at the $1 \%$ level. This result is robust to possible deviations from non-normality, since it also holds for the non-parametric Kruskal-Wallis test statistic. Our findings are consistent with the investment opportunities hypothesis that secured debt financing is more valuable for issuing firms with high growth opportunities than for those with low growth opportunities. Secured debt financing performs better in alleviating the asset substitution and underinvestment problems for firms with more growth options.

To test the robustness of our results, we also divide our sample firms according to whether the announcing firms have $q$ greater or less than the median for the whole sample. High- $q$ (low- $q$ ) firms are firms with $q$ above (below) the sample median. As also shown in Panel A, high- $q$ firms have a positive average (median) two-day announcement-period abnormal return whereas low- $q$ firms have a negative one. Furthermore, the mean difference between the abnormal returns for high- $q$ and low- $q$ firms is again statistically significant. These findings are hence also consistent with the investment opportunities hypothesis. 


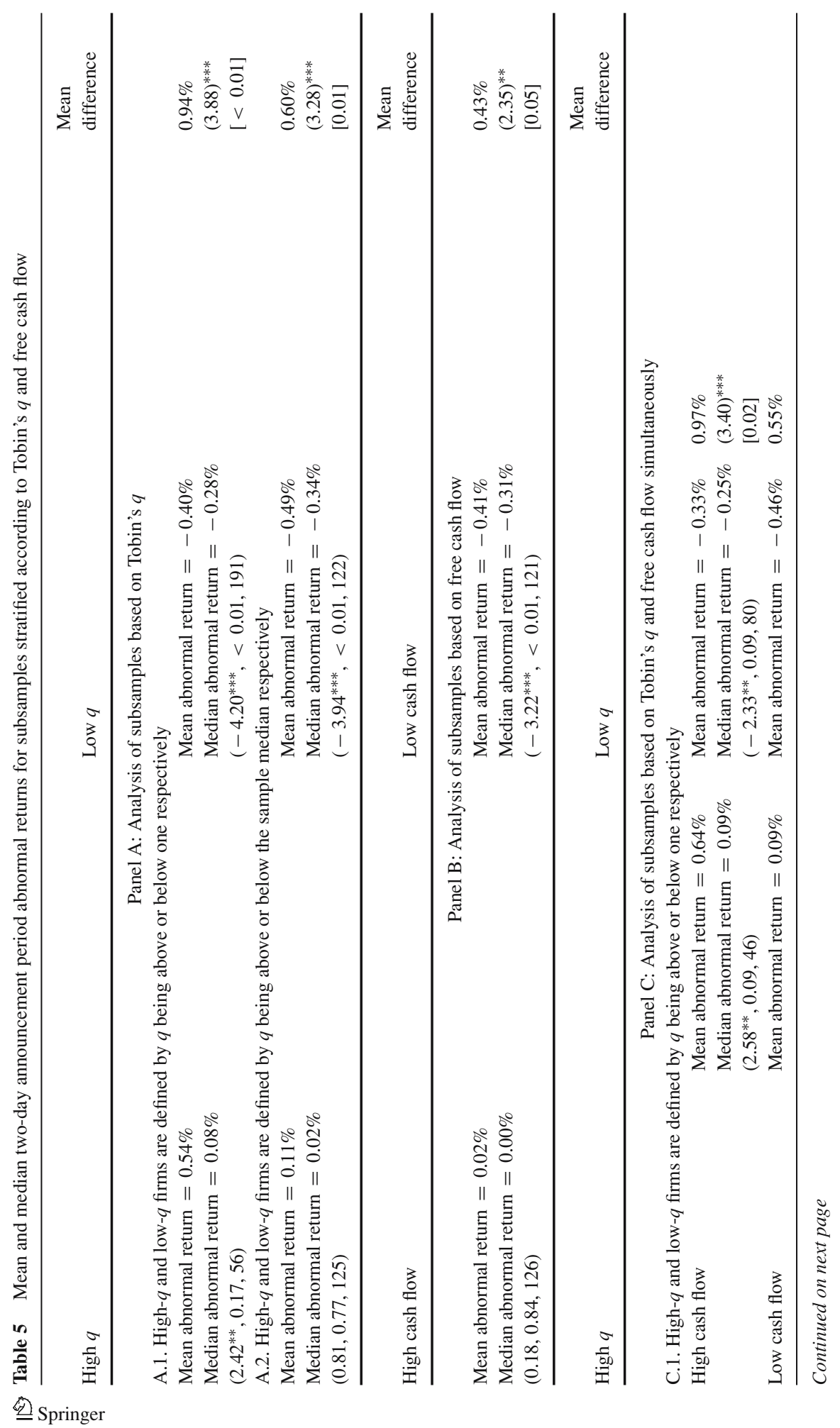




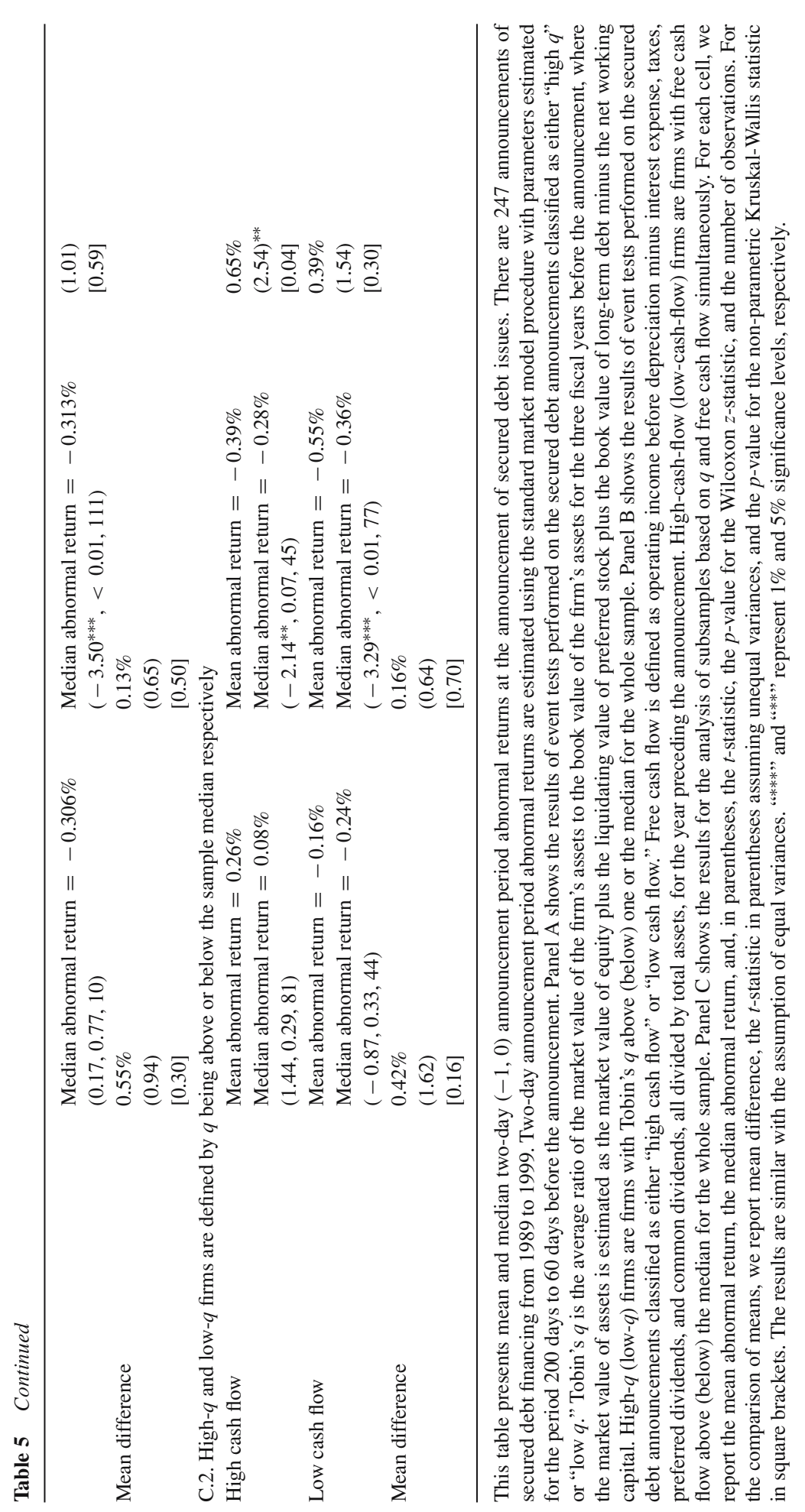


In Panel B, Table 5, we investigate the importance of free cash flow in explaining the announcement effect associated with secured debt offerings. High-cash-flow (lowcash-flow) firms have a free cash flow ratio above (below) the median for the whole sample. This classification follows that of Lang et al. (1991), Howe et al. (1992), and others. We find that high-cash-flow firms have an insignificantly positive average two-day announcement-period abnormal return whereas low-cash-flow firms have a significantly negative one. Furthermore, the mean difference between the abnormal returns for high-cash-flow and low-cash-flow firms is $0.43 \%$, statistically significant at the $5 \%$ level. This result is robust to possible deviations from non-normality, since it also holds for the non-parametric Kruskal-Wallis test statistic. Therefore, high-cashflow firms have higher abnormal returns than low-cash-flow firms, the opposite of what would be expected under the free cash flow hypothesis that the value of secured debt financing is inversely related to the issuing firms' levels of existing free cash flow.

We also present a $2 \times 2$ table in Panel C, Table 5, for our sample firms stratified according to $q$ and free cash flow simultaneously, where high- $q$ and low- $q$ firms are defined by $q$ being above or below one respectively. Free cash flow agency costs may depend upon the firm's investment opportunities since firms with fewer (more) growth opportunities are more (less) likely to have free cash flow. Therefore, the free cash flow hypothesis predicts that low- $q$ /high-cash-flow (high- $q$ /low-cash-flow) firms have the highest (lowest) potential agency costs associated with secured debt issues, and hence should have the lowest and negative (highest and positive) announcement-period abnormal returns.

Our results show that the subsample of low- $q$ /high-cash-flow firms has a significantly negative average (median) abnormal return of $-0.33 \%(-0.25 \%)$. However, the subsample of low- $q$ /low-cash-flow firms has the lowest and significantly negative average and median abnormal returns, while the subsample of high- $q$ /high-cash-flow firms has the highest and significantly positive average and median abnormal returns. Furthermore, there is no statistically significant difference in average abnormal returns between low- $q$ /high-cash-flow and low- $q$ /low-cash-flow firms, and between high- $q$ /high-cash-flow and high- $q$ /low-cash-flow firms. These results do not support the free cash flow hypothesis.

Results in Panel C, Table 5, provide some support for the investment opportunities hypothesis. For each of the subsamples of high-cash-flow and low-cash-flow firms, high $q$ firms have generally higher average abnormal returns than do low $q$ firms, although the difference is statistically significant only for the high-cash-flow firms.

We also present the results for our sample firms stratified according to $q$ and free cash flow simultaneously when high- $q$ and low- $q$ firms are defined by $q$ being above or below the sample median respectively, as shown in Panel C, Table 5. The results are similar. In our sample of secured debt issues, the investment opportunities hypothesis is supported whereas the free cash flow hypothesis is not.

\section{Cross-sectional regression results}

In this section, we first report the regression estimates of abnormal returns on Tobin's $q$ and free cash flow. We then present the regression results controlling for other potential explanatory variables. 


\subsection{Regressions without controlling for other potentially influential factors}

Table 6 presents cross-sectional regression analyses of the announcement-period abnormal returns on Tobin's $q$ and free cash flow for our sample of secured debt issues. The $t$-values are computed with heteroskedasticity-consistent standard errors if tests reject homoskedasticity at the $10 \%$ significance level (White, 1980). ${ }^{10}$ The significance of investment opportunities and free cash flow are tested separately in Models 1 and 2, respectively. We find in Model 1 that the coefficient for the $q$ variable is positive and statistically significant at the $1 \%$ level. This finding supports the investment opportunities hypothesis that secured debt financing is more valuable for issuing firms with good growth opportunities than for those with poor growth opportunities. In Model 2 we find that the coefficient for the free cash flow variable is significantly positive. That is, high-cash-flow firms have higher abnormal returns than low-cash-flow firms, the opposite of what would be expected under the free cash flow hypothesis. The results in Models 1 and 2 are consistent with those of Panels A and B, Table 5.

In Model 3 we test jointly for the significance of investment opportunities and free cash flow. We find that the coefficient for the $q$ variable is statistically positive at the $1 \%$ level whereas that for the free cash flow variable is not statistically significant at the $10 \%$ level. The results in Model 3 are consistent with those of Panel C, Table 5. Therefore, we find again that for our sample of secured debt offerings, the investment opportunities hypothesis is supported, but the free cash flow hypothesis is not.

In Model 4 we add a dummy variable with a value of one if the firm has $q$ below one and has a free cash flow ratio above the sample median, and zero otherwise. ${ }^{11}$ As explained in Section III, this overinvestment dummy indicates that firms have both low growth opportunities and high free cash flow. The free cash flow hypothesis predicts that low- $q$ /high-cash-flow firms have the highest potential agency costs associated with secured debt issues, and hence should have the most unfavorable announcement-period abnormal returns. Therefore, if the free cash theory holds, the overinvestment dummy should be significantly negative. Model 4 shows that the overinvestment dummy is negative, but statistically insignificant at the $10 \%$ level or any other conventional significance level. The results are consistent with those of Panel C, Table 5. We again show that for our sample of secured debt offerings, the free cash flow hypothesis is not supported.

\subsection{Regressions controlling for other potentially influential factors}

The analysis so far does not control for other potential determinants of the stock price reaction to the announcements of secured debt issues. The literature, however, suggests that several other factors could also influence the abnormal returns associated with secured debt offerings. These factors include taxes, asset riskiness, firm quality, asset specificity, firm size, and the maturity and size of the secured debt issued. We discuss these potentially important variables as follows.

\footnotetext{
10 The results are similar if we re-estimate the regressions using weighted least squares, with the weights equal to the reciprocal of the standard deviation of the market model residual.

11 The results in Table 6 are similar when the overinvestment dummy variable has a value of one if the firm has $q$ below the sample median and has a free cash flow ratio above the sample median, and zero otherwise. 
Table 6 Cross-sectional regression analyses of announcement period abnormal returns on Tobin's $q$ and free cash flow

\begin{tabular}{llccc}
\hline & \multicolumn{4}{c}{ Model } \\
\cline { 2 - 5 } Variable & $(1)$ & $(2)$ & $(3)$ & $(4)$ \\
\hline Intercept & -0.0197 & -0.0134 & -0.0205 & -0.0199 \\
& $(-6.27)^{* * *}$ & $(-5.10)^{* * *}$ & $(-6.41)^{* * *}$ & $(-5.87)^{* * *}$ \\
Tobin's $q$ & 0.0193 & & 0.0157 & 0.0145 \\
& $(5.90)^{* * *}$ & & $(3.71)^{* * *}$ & $(3.03)^{* * *}$ \\
Free cash flow & & 0.1159 & 0.0412 & 0.0506 \\
& & $(4.66)^{* * *}$ & $(1.31)$ & $(1.42)$ \\
Overinvestment & & & -0.0012 \\
dummy (=1 if & & & & $(-0.57)$ \\
the firm has low $q$ & & & & \\
and high cash & & & & 247 \\
flow; 0 otherwise) & & & & 0.123 \\
$N$ & 247 & 247 & $18.30^{* * *}$ & $12.28^{* * *}$ \\
Adjusted $R^{2}$ & 0.121 & 0.078 & & \\
$F$-value & $34.80^{* * *}$ & $21.73^{* * *}$ & & \\
\hline
\end{tabular}

This table presents cross-sectional regression analyses of announcement period abnormal returns on Tobin's $q$ and free cash flow for the sample of secured debt issues. The dependent variable is the two-day $(-1,0)$ announcement-period abnormal return for the announcing firm. Two-day announcement period abnormal returns are estimated using the standard market model procedure with parameters estimated for the period 200 days to 60 days before the announcement. Tobin's $q$ is the average ratio of the market value of the firm's assets to the book value of the firm's assets for the three fiscal years before the announcement, where the market value of assets is estimated as the market value of equity plus the liquidating value of preferred stock plus the book value of long-term debt minus the net working capital. High- $q$ (low- $q$ ) firms are firms with Tobin's $q$ above (below) one. Free cash flow is defined as operating income before depreciation minus interest expense, taxes, preferred dividends, and common dividends, all divided by total assets, for the fiscal year preceding the announcement. High-cash-flow (low-cash-flow) firms are firms with free cash flow above (below) the median for the whole sample. The $t$-values in parentheses are computed with heteroskedasticity-consistent standard errors if tests reject homoskedasticity at the $10 \%$ significance level (White, 1980). “***” represents a 1\% significance level

\subsubsection{Taxes}

The tax system encourages firms with higher tax rates to issue more debt that bears interest and is fully deductible from taxable income (DeAngelo and Masulis, 1980). The interest payments on risky debt include a default premium that is tax deductible as paid. Therefore, the tax system encourages firms with higher tax rates to issue the lowest priority and hence most risky debt claims in order to increase the value of the tax shield (Scholes and Wolfson, 1992). This prediction implies that for firms facing higher tax rates, subordinated debt offerings are more valuable while secured debt offerings are less valuable. In examining the determinants of various components of corporate liabilities as a proportion of total long-term fixed claims, Barclay and Smith (1995b) find that firms with higher tax rates use more secured debt. Their results are the opposite of what would be expected under the tax hypothesis. In our cross-sectional regression analyses of the announcement-period abnormal returns for the sample of secured debt issues, we also estimate the effects of the firm's tax status. We approximate a firm's tax rate with tax expense divided by pre-tax income for the fiscal year preceding the announcement (as in Barclay and Smith, 1995b; Sharpe 
and Nguyen, 1995; Stohs and Mauer, 1996; and others). ${ }^{12}$ We expect that the market response to a secured debt announcement is inversely related to the firm's tax rate.

\subsubsection{Asset riskiness}

Scott (1977) shows that the value of secured debt increases with the firm's likelihood of non-payment. Leeth and Scott (1989) argue that a high probability of non-payment magnifies the interest rate reduction associated with the use of secured debt. Boot et al. (1991), Rajan and Winton (1995), and Myers and Rajan (1998) suggest that riskier borrowers should pledge more collateral. Therefore, the various theories predict that secured debt offerings are more valuable for firms with a higher likelihood of non-payment, such as greater asset riskiness. Following Titman and Wessels (1988), MacKie-Mason (1990), and others, we use the volatility of earnings as a proxy for the firm's asset riskiness. ${ }^{13}$ Firms with a higher volatility of earnings are expected to experience better share price responses associated with the announcements of secured debt issues.

\subsubsection{Firm quality}

When lenders have less information regarding the quality of the borrowers' projects, borrowers may attempt to signal their credit worthiness to lenders by using secured debt (Chan and Kanatas, 1985; Besanko and Thakor, 1987; Chan and Thakor, 1987; Igawa and Kanatas, 1990). With secured debt, borrowers benefit from a lower interest rate, but suffer from the potential loss of collateral. With a high quality project, the expected costs of losing the collateral could be small relative to the benefits of a lower interest rate. Therefore, for signalling purposes secured debt offerings are more valuable for high-quality (undervalued) firms than for low-quality (overvalued) firms when information asymmetries exist between borrowers and lenders. Following Barclay and Smith (1995a, b) and Stohs and Mauer (1996), we use the firm's abnormal future earnings to empirically measure firm quality. High quality (undervalued) firms are likely to have positive future abnormal earnings while low quality (overvalued) firms are likely to have negative future abnormal earnings. We expect that the market's responses to secured debt announcements are more favorable for firms with higher abnormal future earnings.

\footnotetext{
12 We have also employed the following alternative tax proxies: (1) a dummy variable that is equal to one if the announcing firm has any tax-loss carryforwards in the year prior to the announcement, and zero otherwise (as in Barclay and Smith (1995b)); (2) the ratio of tax-loss carryforwards to operating income or sales for the year preceding the announcement (as in MacKie-Mason (1990), and Sharpe and Nguyen (1995)); and (3) the announcing firm's use of investment tax credits in the year prior to the announcement (as in MacKie-Mason (1990), and Barclay and Smith (1995b)). Our conclusions in this study remain unchanged.

${ }^{13}$ Our results are similar if asset riskiness is measured by the coefficient of variation in earnings: the standard deviation of the first difference in the announcing firm's historical EBDIT divided by the mean level of the book value of total assets for ten years preceding the announcement (as in MacKie-Mason, 1990; Stohs and Mauer, 1996; and others).
} 


\subsubsection{Asset specificity}

High asset specificity reduces creditor concerns with asset substitution and hence the value of security provision (Jackson and Kronman, 1979; Smith and Warner, 1979a, b). Therefore, secured debt issues are less valuable for firms with more specialized assets (Leeth and Scott, 1989). Following Titman and Wessels (1988) and others, a firm's asset specificity is measured by its R\&D and selling intensity. As argued by Titman and Wessels (1988), R\&D intensity measures specificity, because firms that use specialized assets to produce unique products are likely to conduct $R \& D$ since their innovations cannot be easily duplicated. In addition, successful R\&D projects are likely to lead to unique products, which are produced using specialized assets. Firms with relatively specialized assets and unique products are also expected to advertise more and in general spend more in promoting and selling their products. Therefore, the market response to secured debt announcements should be inversely related to the firm's level of R\&D and selling intensity.

\subsubsection{Firm size}

There are several possible reasons why secured debt financing is more valuable for smaller firms. First, Smith and Warner (1979b) argue that smaller firms, more likely to be liquidated in bankruptcy, should use secured debt financing since liquidation assures that secured bondholders receive title to the pledged assets. Second, smaller firms tend to have a higher probability of non-payment (Altman et al., 1977). Since a high probability of non-payment magnifies the interest rate reduction associated with the use of secured debt (Leeth and Scott, 1989), there is an incentive for smaller firms to use secured debt financing. Finally, Chan and Kanatas (1985) suggest that smaller firms, with less information available to lenders, may use secured debt to signal their project quality. In examining the priority structure of corporate liabilities, Barclay and Smith (1995b) document that smaller firms issue significantly more secured debt. Following Barclay and Smith (1995a and b) and others, we use the market value of the firm as a measure of firm size. We expect that the market's responses to secured debt announcements are more favorable for smaller firms.

\subsubsection{Debt maturity}

Debt maturity may increase the value of secured debt because of the higher probability of default on long-term debt (Leeth and Scott, 1989). As the number of time periods increases, the likelihood that the firm faces an adverse event precipitating bankruptcy increases. Because the value of secured debt increases with the firm's likelihood of default risk, long-term secured debt issues are more valuable for the issuing firms than short-term ones. In addition, with long-term debt, firms are more likely to substitute high-risk projects for low-risk projects since they can gradually and economically alter projects in subtle ways that impair the debtholders (Jackson and Kronman, 1979). Firms with long-term debt are also more likely to reject positive NPV projects since they have more opportunities to exercise the real investment options (Myers, 1977). Therefore, secured debt issues perform better in alleviating the asset substitution and underinvestment problems for long-term financing. This suggests that secured debt 
issues are more valuable when they are long-term. ${ }^{14}$ We hence expect that the market's responses to secured debt announcements are more favorable for long-term financing than for short-term financing. ${ }^{15}$

\subsubsection{Issue size}

The size of secured debt issues could influence the announcement effect associated with secured debt offerings. A relatively large offering of debt might convey more information than smaller offerings and so elicit larger price reactions (Miller and Rock, 1985; Szewczyk, 1992). In addition, Jackson and Kronman (1979) and Boot et al. (1991) argue that the fixed monitoring and administrative costs associated with secured debt (e.g. the costs of asset appraisals, inspections, borrower reports, etc.) fall on a per unit basis as the size of the secured debt issued rises, making secured debt financing more economical. They suggest that secured debt issues are more valuable for a large amount of financing ceteris paribus. Following Eckbo (1986), we measure issue size by the face value of the secured debt issue relative to the market value of common stock as of the month prior to the month of the issue.

In Table 7, we estimate a multivariate cross-sectional regression of the announcement-period abnormal returns controlling for these factors. The number of observations varies across regressions because of data availability. Model 1 shows that the coefficient for the $q$ variable is positive and statistically significant at the 5\% level. The coefficient for the free cash flow variable is significantly positive at the $10 \%$ level, the opposite of what would be expected under the free cash flow hypothesis. Furthermore, the overinvestment dummy is statistically insignificant. Therefore, our results are robust when other potentially influential factors are controlled for. The investment opportunities hypothesis still holds while there is no support for the free cash flow hypothesis.

The only control variable that is significant in Model 1 is the volatility of earnings variable. Firms with a higher volatility of earnings experience more favorable share price responses associated with the announcements of secured debt issues. This result is consistent with the theoretical prediction that secured debt issues are more valuable for firms with a higher likelihood of non-payment.

Model 1 also shows that the wealth effect of secured debt offerings is not significantly related to the announcing firm's tax rate, abnormal earnings, R\&D and selling intensity, and size, as well as the maturity and size of the secured debt issued. While the tax rate, R\&D and selling intensity, and debt maturity variables have signs consistent with the theoretical predictions, they are not statistically significant at the conventional levels. The evidence implies that these factors suggested in the literature are relatively unimportant in explaining the announcement effect associated with secured debt issues.

\footnotetext{
14 In examining the incidence of secured debt, Leeth and Scott (1989) document that debt maturity positively increases the probability of secured debt financing.

15 Stulz and Johnson (1985), on the other hand, argue that long-term secured debt issues are less valuable for the issuing firms. They assume that new debt has the same maturity as the existing (unsecured) debt, and demonstrate that the value of a security provision is a decreasing function of time to maturity.
} 
Table 7 Cross-sectional regression analyses of announcement period abnormal returns on Tobin's $q$, free cash flow, and control variables

\begin{tabular}{|c|c|c|c|}
\hline \multirow[b]{2}{*}{ Variable } & \multicolumn{3}{|c|}{ Model } \\
\hline & $(1)$ & (2) & (3) \\
\hline Intercept & $-0.0239(-2.19)^{* *}$ & $-0.0297(-2.46)^{* *}$ & $-0.0324(-2.80)^{* * *}$ \\
\hline Tobin's $q$ & $0.0131(2.45)^{* *}$ & $0.0112(2.02)^{* *}$ & $0.0120(2.14)^{* *}$ \\
\hline Free cash flow & $0.0697(1.80) *$ & $0.1017(2.30)^{* *}$ & $0.0995(2.37)^{* *}$ \\
\hline $\begin{array}{l}\text { Overinvestment dummy } \\
\text { (=1 if the firm has low } \\
q \text { and high cash flow; } 0 \\
\text { otherwise) }\end{array}$ & $-0.0014(-0.62)$ & $-0.0001(-0.06)$ & $-0.0016(-0.71)$ \\
\hline Tax rate & $-0.0028(-0.40)$ & $-0.0040(-0.50)$ & $-0.0016(-0.24)$ \\
\hline Volatility of earnings & $0.0004(2.03)^{* *}$ & $0.0004(1.87) *$ & $0.0003(1.79) *$ \\
\hline Abnormal earnings & $-0.0007(-0.04)$ & $0.0034(0.20)$ & $-0.0007(-0.04)$ \\
\hline $\begin{array}{l}\mathrm{R} \& \mathrm{D} \text { and selling } \\
\text { intensity }\end{array}$ & $-0.0069(-0.94)$ & $-0.00003(-0.004)$ & $0.0019(0.22)$ \\
\hline Log of firm size & $0.0002(0.16)$ & $-0.0001(-0.13)$ & $0.0002(0.20)$ \\
\hline Log of term to maturity & $0.0012(0.95)$ & $0.0001(0.07)$ & $0.0005(0.35)$ \\
\hline Issue size & $-0.0012(-0.32)$ & $0.0006(0.15)$ & $0.0004(0.09)$ \\
\hline Utilities dummy & & $0.0080(2.33)^{* *}$ & $0.0069(2.05)^{* *}$ \\
\hline Bond rating & & $0.0009(1.02)$ & \\
\hline Debt-equity ratio & & & $0.0017(1.16)$ \\
\hline$N$ & 239 & 233 & 237 \\
\hline Adjusted $R^{2}$ & 0.117 & 0.142 & 0.130 \\
\hline$F$-value & $4.16^{* * *}$ & $4.19^{* * *}$ & $3.96^{* * *}$ \\
\hline
\end{tabular}

This table presents cross-sectional regression analyses of announcement period abnormal returns on Tobin's $q$, free cash flow, and control variables for the sample of secured debt issues. The dependent variable is the two-day $(-1,0)$ announcement-period abnormal return for the announcing firm. Tobin's $q$, free cash flow, tax rate, volatility of earnings, abnormal earnings, R\&D and selling intensity, firm size, issue size, and debt-equity ratio are defined in Table 3. High- $q$ (low- $q$ ) firms are firms with Tobin's $q$ above (below) one. High-cash-flow (low-cash-flow) firms are firms with free cash flow above (below) the median for the whole sample. Utilities dummy is equal to one if the announcing firm is a gas or electric utility (SIC codes of 4900-4939), and zero otherwise. The bond rating is equal to one if the bond rating by Moody's is Aaa, through six if it is $\mathrm{B}$, and seven if it is unrated. The $t$-values in parentheses are computed with heteroskedasticity-consistent standard errors if tests reject homoskedasticity at the $10 \%$ significance level (White, 1980). The number of observations varies across regressions because of data availability. "****, “**”, and “*” represent $1 \%, 5 \%$, and $10 \%$ significance levels, respectively

In Model 2, we repeat Model 1 by including a regulated utility dummy and a bond rating variable. The regulated utility dummy is equal to one if the announcing firm is a gas or electric utility (SIC codes of 4900-4939), and zero otherwise (as in Barclay and Smith (1995a and b), and others). Barclay and Smith (1995b) document that regulated utilities use secured debt more intensively since secured debt offerings are advantageous for those firms by prohibiting regulators from transferring wealth from investors to customers (Smith, 1986). The bond rating variable is also included in the model as a proxy of the risk of the bonds, because the bond issues' impact on the firm's market value may depend upon the risk of the bond issued (Myers and Majluf, 1984). This variable is equal to one if the bond rating by Moody's is Aaa, through six if it is B, and seven if it is unrated (similar to Barclay and Smith, 1995a; and Stohs and Mauer, 1996). 
Model 2 shows that after also controlling for the regulated utility dummy and the bond rating variable, the investment opportunities hypothesis still holds while the free cash flow hypothesis is still not supported. The only control variables that are significant in Model 2 are the volatility of earnings and the regulated utility dummy, both having signs consistent with the theoretical predictions. Firms with a higher likelihood of non-payment and regulated utilities experience more favorable share price responses associated with the announcements of secured debt issues since secured debt issues are more valuable for those firms.

Finally, in Model 3 we use the debt-equity ratio as an alternative proxy for the risk of the secured debt issued, where the debt-equity ratio is measured as the sum of the issuing firm's short-term and long-term debt divided by the market value of common stock for the year preceding the announcement (as in Eckbo (1986)). The results in Model 3 are similar to those in Model 2. The valuation effect of secured debt offerings is more favorable for firms with higher growth opportunities, more free cash flow, and greater asset riskiness as well as for regulated utilities. The rest of the potentially influential variables, including the debt-equity ratio, are relatively unimportant in assessing the valuation impact of secured debt offerings.

\section{Conclusion}

This paper examines the importance of investment opportunities and free cash flow in explaining the stock valuation effects of secured debt offerings. While previous empirical studies have examined the overall valuation effect of secured debt issues and the determinants of a firm's propensity to use secured debt, our study is the first to provide a better understanding of the relative importance of the potentially influential factors in explaining the variation in the stock valuation impact of secured debt issues. The valuation impact is measured in terms of the abnormal stock returns to the issuing firms associated with the announcements of secured debt issues.

We investigate a sample of firms that announced secured debt issues during the period 1989-1999. We show that consistent with previous studies, announcements of secured debt offerings are, on average, associated with significantly negative abnormal returns. We further divide our sample by firms with good and poor investment opportunities. We find that announcing firms with favorable investment opportunities have a positive response to the announcements of their secured debt offerings, whereas firms with poor investment opportunities have a negative response to such announcements. In cross-sectional regression analyses, we show a significantly positive relation between the market's response to announcements of secured debt offerings and the announcing firm's investment opportunities. Our results support the investment opportunities hypothesis that secured debt financing is more valuable for issuing firms with high growth opportunities.

In contrast, we find no support for the free cash flow hypothesis. We show that the results for the relation between the market's response to announcements of secured debt offerings and the announcing firm's free cash flow are inconsistent with the theoretical predictions by the free cash flow hypothesis. Our evidence suggests that Jensen's free cash flow theory may not apply to secured debt offerings. Our findings 
shed light on the role of free cash flow in explaining the valuation effects of secured debt issues.

Our results still hold even after controlling for other potential explanatory factors suggested in the literature. These factors include firm and issue characteristics, such as taxes, asset riskiness, firm quality, asset specificity, firm size, regulation, and the maturity, size, and risk of the secured debt issued. We also find that firms with greater asset riskiness and regulated utilities experience significantly more favorable share price responses associated with the announcements of secured debt issues. The value of secured debt increases with the firm's likelihood of non-payment, and secured debt offerings are more advantageous for regulated utilities by prohibiting regulators from transferring wealth from investors to customers. The other control variables do not significantly affect the announcement effect in our sample, suggesting that they are relatively unimportant in explaining the valuation effects of secured debt offerings.

Acknowledgment The authors wish to thank an anonymous referee, Dosoung Choi, Kim Wai Ho, Frank C. Jen, Cheng-few Lee (the Editor), Chiuling Lu, Yang-pin Shen, and seminar participants at the 2003 FMA Annual Meeting for helpful comments and suggestions. Wenchun Lin provided very capable research assistance. Sheng-Syan Chen acknowledges funding from the National Science Council in Taiwan (NSC92-2416-H155-018).

\section{References}

Altman EI, Haldeman RG, Narayanan P (1977) Zeta analysis: a new model to identify bankruptcy risk of corporations. J Bank Financ 1:29-54

Barclay MJ, Litzenberger RH (1988) Announcement effects of new equity issues and the use of intraday price data. J Financ Econ 21:71-99

Barclay MJ, Smith CW Jr (1995a) The maturity structure of corporate debt. J Financ 50:609-631

Barclay MJ, Smith CW Jr (1995b) The priority structure of corporate liabilities. J Financ 50:899-917

Berkovitch E, Kim EH (1990) Financial contracting and leverage induced over- and under-investment incentives. J Financ 45:765-794

Besanko D, Thakor AV (1987) Collateral and rationing: sorting equilibria in monopolistic and competitive credit markets. Int Econ Rev 28:671-689

Boot A, Thakor AV, Udell GF (1991) Secured lending and default risk: equilibrium analysis, policy implications, and empirical results. Econ J 101:458-472

Chan YS, Kanatas G (1985) Asymmetric valuations and the role of collateral in loan agreements. J Money, Credit Bank 17:84-95

Chan YS, Thakor AV (1987) Collateral and competitive equilibria with moral hazard and private information. J Financ 42:345-363

Chung KH, Pruitt SW (1994) Simple approximation of Tobin's $q$. Finan Manage 23:70-74

DeAngelo H, Masulis RW (1980) Optimal capital structure under corporate and personal taxation. J Finan Econ 8:3-29

Denis DJ (1994) Investment opportunities and the market reaction to equity offerings. J Finan Quant Anal 29:159-177

Diamond DW (1991) Debt maturity structure and liquid risk. Q J Econ 106:709-737

Diamond DW (1993) Seniority and maturity of debt contracts. J Finan Econ 33:341-368

Dodd P, Warner JB (1983) On corporate governance: a study of proxy contests. J Finan Econ 11:401-438

Eckbo BE (1986) Valuation effects of corporate debt offerings. J Finan Econ 15:119-151

Fridson MS, Gao Y (2002) Defaulted bond returns by seniority class. J Fixed Income 12:50-57

Guedes J, Opler T (1996) The determinants of the maturity of corporate debt issues. J Financ 51:1809-1833

Holderness CG, Kroszner RS, Sheehan DP (1999) Were the good old days that good? Changes in managerial stock ownership since the great depression. J Financ 54:435-469

Howe KM, He J, Kao GW (1992) One-time cash flow announcements and free cash-flow theory: share repurchases and special dividends. J Financ 47:1963-1975 
Howton SD, Howton SW, Perfect SB (1998) The market reaction to straight debt issues: the effects of free cash flow. J Finan Res 21:219-228

Igawa K, Kanatas G (1990) Asymmetric information, collateral, and moral hazard. J Finan Quant Anal 25:469-490

Jackson TH, Kronman AT (1979) Secured financing and priorities among creditors. Yale Law J 88:11431182

Jensen MC (1986) Agency costs of free cash flow, corporate finance, and takeovers. Am Econ Rev 76:323329

Jensen MC, Meckling WH (1976) Theory of the firm: managerial behavior, agency costs and ownership structure. J Finan Econ 3:305-360

Kang JK, Stulz RM (1996) How different is Japanese corporate finance? An investigation of the information content of new security issues. Rev Finan Stud 9:109-139

Kleidon AW (1986) Variance bounds tests and stock price valuation models. J Political Econ 94:953-1001

Lang LHP, Litzenberger RH (1989) Dividend announcements: cash flow signalling vs. free cash flow hypothesis? J Finan Econ 24:181-192

Lang LHP., Stulz RM, Walkling RA (1989) Managerial performance, Tobin's $q$, and the gains from successful tender offers. J Finan Econ 24:137-154

Lang LHP., Stulz RM, Walkling RA (1991) A test of the free cash flow hypothesis: the case of bidder returns. J Finan Econ 29:315-335

Leeth JD, Scott JA (1989) The incidence of secured debt: evidence from the small business community. J Finan Quant Anal 24:379-394

Lehn K, Poulsen A (1989) Free cash flow and stockholder gains in going private transactions. J Financ 44:771-787

Lie E (2000) Excess funds and agency problems: an empirical study of incremental cash disbursements. Rev Finan Stud 13:219-248

Lie E (2002) Do firms undertake self-tender offers to optimize capital structure? J Bus 75:609-639

Lindenberg E, Ross S (1981) Tobin's $q$ ratio and industrial organization. J Bus 54:1-32

MacKie-Mason JK (1990) Do taxes affect corporate financing decisions? J Financ 45:1471-1493

Miller MH, Rock K (1985) Dividend policy under asymmetric information. J Financ 32:1031-1051

Myers SC (1977) Determinants of corporate borrowing. J Finan Econ 5:147-175

Myers SC, Majluf NS (1984) Corporate financing and investment decisions when firms have information that investors do not have. J Finan Econ 13:187-221

Myers SC, Rajan RG (1998) The paradox of liquidity. Q J Econ 113:733-771

Rajan R, Winton A (1995) Covenants and collateral as incentives to monitor. J Financ 50:1113-1146

Roberts GS, Viscione JA (1984) The impact of seniority and security covenants on bond yields: a note. J Financ 39:1597-1602

Scholes MS, Wolfson MA (1992) Taxes and business strategy. Prentice Hall, Englewood Cliffs, NJ

Scott JH, Jr (1977) Bankruptcy, secured debt, and optimal capital structure. J Financ 32:1-19

Sharpe SA, Nguyen HH (1995) Capital markets imperfections and the incentive to lease. J Finan Econ 39:271-294

Smith CW Jr. (1986) Investment banking and the capital acquisition process. J Finan Econ 15:3-29

Smith CW Jr, Warner JB (1979a) Bankruptcy, secured debt and optimal capital structure: comment. J Financ 34:247-251

Smith CW Jr, Warner JB (1979b) On financial contracting: an analysis of bond covenants. J Finan Econ 7:117-161

Song MH, Walkling RA (2000) Abnormal returns to rivals of acquisition targets: a test of the 'acquisition probability hypothesis'. J Finan Econ 55:143-172

Stohs MH, Mauer DC (1996) The determinants of corporate debt maturity structure. J Bus 69:279-312

Stulz RM, Johnson H (1985) An analysis of secured debt. J Finan Econ 14:501-521

Szewczyk SH (1992) The intra-industry transfer of information inferred from announcements of corporate security offerings. J Financ 47:1935-1945

Titman S, Wessels R (1988) The determinants of capital structure choice. J Financ 43:1-20

Watts RL, Zimmerman J (1986) Positive accounting theory. Prentice Hall, Englewood Cliffs, NJ

White H (1980) A heteroskedasticity-consistent covariance matrix estimator and a direct test for heteroskedasticity. Econometrica 48:817-838 